\title{
PENERAPAN PRINSIP ARSITEKTUR RAMAH LINGKUNGAN PADA FASILITAS KONSERVASI AIR DI BALIGE, DANAU TOBA
}

\author{
Anri Samuel Pulungan ${ }^{1)}$, Priscilla Epifania Ariaji ${ }^{2)}$ \\ 1) Program Studi S1 Arsitektur Fakultas Teknik, Universitas Tarumanagara, andrisamuel1350@gmail.com \\ 2) Program Studi S1 Arsitektur Fakultas Teknik, Universitas Tarumanagara, priscillae@ft.untar.ac.id
}

Masuk: 03-07-2021, revisi: 14-08-2021, diterima untuk diterbitkan: 23-10-2021

\begin{abstract}
Abstrak
Permasalahan lingkungan hidup saat ini sudah menjadi masalah yang serius di lingkungan Indonesia. Kelangsungan hidup lingkungan alam saat ini mulai banyak yang rusak dan sangat terancam akibat dari perubahan alam, termasuk faktor alam atau faktor dari manusianya itu sendiri. Contohnya seperti pencemaran air akibat aktivitas budidaya ikan dengan keramba jaring apung, seperti material yang digunakan, sisa sisa pakan ikan dan kotoran ikan tersebut yang terus menumpuk pada bagian perairan. Kebanyakan dari permasalahan ini belum memiliki solusi dalam mengatasinya. Sehingga menyebabkan kerusakan alam dan lingkungan yang terus berlanjut dan mengancam bumi ini. Jadi penting untuk meningkatkan kesadaran masyarakat dalam menjaga dan melestarikan lingkungan hidup, terlebih di bidang arsitektur dan lingkungan. Penerapan prinsip arsitektur ramah lingkungan pada proyek bangunan ini dimaksudkan untuk melindungi dan melestarikan sumber daya alam dan sekitarnya, menghemat penggunaan energi, penggunaan material ramah lingkungan, meminimalisir kerusakan lingkungan, menciptakan hubungan dengan ekosistem yang selaras dan ramah terhadap alam dan menghasilkan berbagai inovasi dan konsep perancangan arsitektur yang hemat energi. Proyek arsitektur ini menggabungkan konsep fasilitas konservasi air dan bangunan terapung diatas Danau Toba sebagai sarana edukasi, pendidikan dan hiburan, serta terciptanya wadah bagi masyarakat untuk berusaha, bekerja dan mengenal ekosistem yang terdapat disana, mewadahinya, membangun kesadaran masyarakat yang lebih baik dan menumbuhkan rasa kepedulian yang tinggi terhadap menjaga alam dan lingkungan sekitarnya.
\end{abstract}

Kata Kunci : bangunan terapung; budidaya ikan dengan keramba jaring apung; fasilitas konservasi air; kerusakan lingkungan; pencemaran air; prinsip ramah lingkungan.

\begin{abstract}
Environmental problems have now become a serious problem in the Indonesian environment. The survival of the natural environment is currently starting to be damaged and very threatened due to natural changes, including natural factors or human factors themselves. For example, water pollution due to fish farming activities with floating net cages, such as the material used, the rest of the fish feed and fish waste that continues to accumulate in the waters. Most of these problems do not have a solution to overcome them. This causes ongoing damage to nature and the environment and threatens this earth. So it is important to increase public awareness in protecting and preserving the environment, especially in the fields of architecture and the environment. The application of environmentally friendly architectural principles in this building project is intended to protect and conserve natural and surrounding resources, save energy use, use environmentally friendly materials, minimize environmental damage, create relationships with ecosystems
\end{abstract}


that are harmonious and friendly to nature and produce various innovations and design concepts. energy efficient architecture. This architectural project combines the concept of water conservation facilities and floating buildings on Lake Toba as a means of education, education and entertainment, as well as creating a forum for the community to do business, work and get to know the ecosystem that is there, accommodate it, build better public awareness and foster a sense of care. high regard for protecting nature and the surrounding environment

Keywords: environmental damage; environmentally friendly principles; fish farming with floating net cages; floating buildings; water conservation facilities; water pollution.

\section{PENDAHULUAN}

\section{Latar Belakang Masalah}

Masa sekarang, air bersih menjadi masalah yang serius dikarenakan untuk mendapatkan dengan kualitas yang baik sudah sangat sulit. Hal itu dikarenakan pencemaran air dari berbagai macam limbah akibat kegiatan manusia itu sendiri. Sehingga menyebabkan kerusakan lingkungan seperti kualitas dan kuantitas airnya menurun padahal air termasuk barang langka yang paling dominan dibutuhkan manusia di permukaan bumi ini.

Begitu juga dengan Danau Toba yang merupakan danau terbesar di Indonesia dan Asia Tenggara. Keindahan alam di Danau Toba menjadikan daerah disana menjadi prioritas Obyek dan Daya Tarik Wisata (ODTW) di Sumatera Utara. Danau ini sangat sakral dan penting bagi masyarakat di daerah tersebut, selain itu air di Danau ini dimanfaatkan sebagai sumber air minum dan air bersih bagi masyarakat.

Tetapi belakangan ini terjadi pencemaran air Danau Toba akibat limbah dari aktivitas masyarakat dan kegiatan industri yang masuk ke dalam Danau. Danau Toba juga digunakan sebagai tempat membuang berbagai jenis limbah dari kegiatan pertanian sekitar, limbah domestik dari pemukiman dan perhotelan, limbah pariwisata dan transportasi air dan limbah dari sisa pakan ikan kegiatan keramba jaring apung (KJA). Dari hasil studi yang dikumpulkan, didapatkan bahwa pada daerah pemukiman, pelabuhan, objek wisata, perhotelan dan terutama masalah yang diangkat yaitu penggunaan keramba jaring apung terbukti mencemari perairan Danau Toba. Padahal perkembangan budidaya ikan dengan keramba jaring apung di perairan Danau Toba memberikan pengaruh yang positif bagi masyarakat terutama masyarakat lokal di sekitar danau, karena selain meningkatkan nilai produksi ikan dan meningkatkan penghasilan bagi masyarakat petani KJA dan juga mampu memperluas peluang pekerjaan bagi masyarakat, sehingga turut dalam mengurangi angka pengangguran disana.

\section{Rumusan Permasalahan}

Kegiatan budidaya ikan dengan sistem keramba jaring apung di Danau Toba semakin banyak dan tidak terkendali. Hal tersebut terlihat dari jumlah KJA yang beroperasi di perairan Danau Toba sudah melebihi batas yang ditentukan pemerintah setempat, yang berarti juga akan peningkatan jumlah ikan yang akan dibudidayakan dalam KJA. Konsekuensinya peningkatan penggunaan pelet sebagai pakan utama ikan. Berdasarkan hasil penelitian bahwa pakan ikan (pelet) sebagian tidak terkonsumsi oleh ikan dan terbuang ke badan air sebagai limbah. Di samping limbah pakan, ikan dalam KJA juga mengeluarkan limbah sisa metabolisme seperti feses dan urine yang semuanya terbuang ke badan air. Oleh karena itu berdampak serius terhadap kualitas air di Danau Toba, juga berdampak terjadinya perubahan lingkungan di perairan baik 
komponen biotiknya dan abiotik perairan danau Toba. Jadi diperlukan pemahaman dan pengaplikasian dalam mengatasi pencemaran air danau ini.

\section{Tujuan}

Menghasilkan sebuah bangunan arsitektur dengan fokus konsep untuk mengurangi masalah pencemaran air karena keramba jaring apung melalui teknologi dan penanganan lokasi, agar terciptanya wadah bagi masyarakat untuk mengenal ekosistem yang ada di danau dan sarana edukasi, pendidikan dan hiburan, menumbuhkan rasa kepedulian terhadap alam dan lingkungan sekitarnya, mengedukasi masyarakat sehingga membantu pemerintah dalam menjaga lingkungan dan menciptakan generasi anak bangsa yang kreatif, bermoral, dan inovatif.

\section{KAJIAN LITERATUR}

\section{Ekologi dan Eko-Arsitektur}

"Ekologi didefinisikan sebagai ilmu tentang hubungan timbal balik antara makhluk hidup dengan lingkungannya yang saling mempengaruhi segala jenis makhluk hidup (tumbuhan, binatang, manusia) dan lingkungannya (cahaya, suhu, curah hujan, kelembaban, topografi, dan sebagainya). Demikian juga proses kelahiran, kehidupan, pergantian generasi, dan kematian yang semuanya menjadi bagian dari pengetahuan manusia. Proses itu berlangsung terus dan dinamakan sebagai hukum alam" Effendi, Salsabila, dan Malik, (2018: 76).

Eko-arsitektur juga bagian-bagian dari arsitektur biologis (arsitektur kemanusiaan yang memperhatikan kesehatan), arsitektur alternatif, arsitektur matahari (dengan memanfaatkan energi surya), arsitektur bionic (teknik sipil dan konstruksi yang memperhatikan kesehatan manusia), serta biologi pembangunan. Eko-arsitektur mencakup keselarasan antara manusia dan lingkungan alamnya.

Arsitektur ekologis merupakan pembangunan berwawasan lingkungan, dimana memanfaatkan potensi alam semaksimal mungkin. Tujuan dari ekologi arsitektur (desain ekologis) adalah menciptakan sebuah bangunan atau lingkungan binaan yang menggunakan energi, air dan sumber daya lain seefisien mungkin, melindungi kesehatan penghuni dan meningkatkan produktivitas pengguna serta mengurangi limbah, polusi dan degradasi lingkungan. Arsitektur yang sadar lingkungan holistik, hemat energi, material ramah lingkungan, peka terhadap iklim. Melampaui Ekologi.

Melampaui ekologi adalah sebuah cara pikir untuk melihat ekologi yang ada sekarang, mengolah dan membuat sesuatu yang bertujuan menjamin ketersedian sumber daya alam yang selalu cukup, baik untuk sekarang maupun nantinya yang pembangunannya dipengaruhi dan mempengaruhi lingkungan hidup. Proses dalam ekosistem diusahakan agar tetap terjadi secara berkelangsungan dalam keterkaitan keanekaragaman, kelestarian, keserasian dan keseimbangan lingkungan untuk kebaikan dan kehidupan.

Beberapa parameter melampaui ekologi yang diterapkan :

- Energy and emission adalah kemampuan untuk menerapkan zero $\mathrm{CO} 2$ emission dalam pengoperasionalan bangunan dan meminimalisir efek karbon dalam material dan konstruksi.

- Adaptation adalah kemampuan untuk melakukan riset dan desain yang berkaitan dengan berbagai dampak seperti naiknya suhu bumi, naiknya permukaan danau, kekeringan, banjir, kelangkaan pangan, perubahan populasi.

$>$ Resilience adalah kemampuan untuk membangun kelanjutan hunian dan pemulihan cepat setelah kejadian guncangan, bencana alam, gangguan listrik atau iklim.

> Sustainable digital adalah kemampuan untuk melihat data-data lingkungan sebagai Big Data dalam menentukan taktik dan strategi dalam membangun kualitas spasial. 
> New technology adalah kemampuan memanfaatkan teknologi terbaru untuk meningkatan kualitas dan terapan ruang konstruksi dan program bangunan.

- Context adalah kemampuan dalam melihat posisi tempat dalam hubungan dengan lingkungan (flora, fauna, biotik - abiotik) dimana sebuah konfigurasi keruangan akan ditempatkan.

\section{Keramba Jaring Apung (KJA)}

"Keramba Jaring Apung sebagai tempat pemeliharaan ikan yang terbuat dari bahan jaring yang memungkinkan keluar masuknya air dengan leluasa, sehingga terjadi pertukaran ke perairan sekitarnya. Komponen-komponen Keramba Jaring Apung terdiri dari kerangka atau bingkai, pelampung, jangkar, pemberat jaring, penutup kantung jaring, bangunan fisik dan peralatan pendukung lainnya" Hartami, (2008 : 93).

"Di sisi lain, Keramba Jaring Apung adalah wadah pemeliharaan ikan terbuat dari jaring yang di bentuk segi empat,bulat atau silindris diapungkan dalam air permukaan menggunakan pelampung dan kerangka kayu, bambu, atau besi, serta sistem penjangkaran. Keramba Jaring Apung ini juga merupakan proses yang luwes untuk mengubah nelayan kecil tradisional menjadi pengusaha agribisnis perikanan" Abdulkadir, (2010).

\section{Jenis Keramba Jaring Apung}

Pada umumnya semua bahan dalam pembuatan alat alat KJA pasti sama. Hanya saja bentuk dan ukurannya banyak yang disesuaikan dengan kebutuhan di lapangan. Terdapat beberapa tipe atau jenis keramba jaring apung yang saat ini sering digunakan para petani KJA, yaitu keramba jaring apung bundar, kotak, dan oktagonal.

\section{Keramba Jaring Apung Bulat}

Jenis keramba ini biasanya berbentuk bulat dengan ukuran diameter 8 hingga 50 meter, tergantung kebutuhan keramba jenis ini biasa digunakan petani KJA. Namun, ada beberapa petani KJA yang menggunakannya di waduk atau danau karena memiliki kedalaman yang cukup dan area yang luas. Sedangkan keramba berukuran 20 meter ke atas dirancang khusus untuk budidaya berskala besar. Ada pula keramba jaring apung bulat dengan diameter berkisar 8-15 meter, yang dirancang untuk budidaya industri kecil dan menengah.

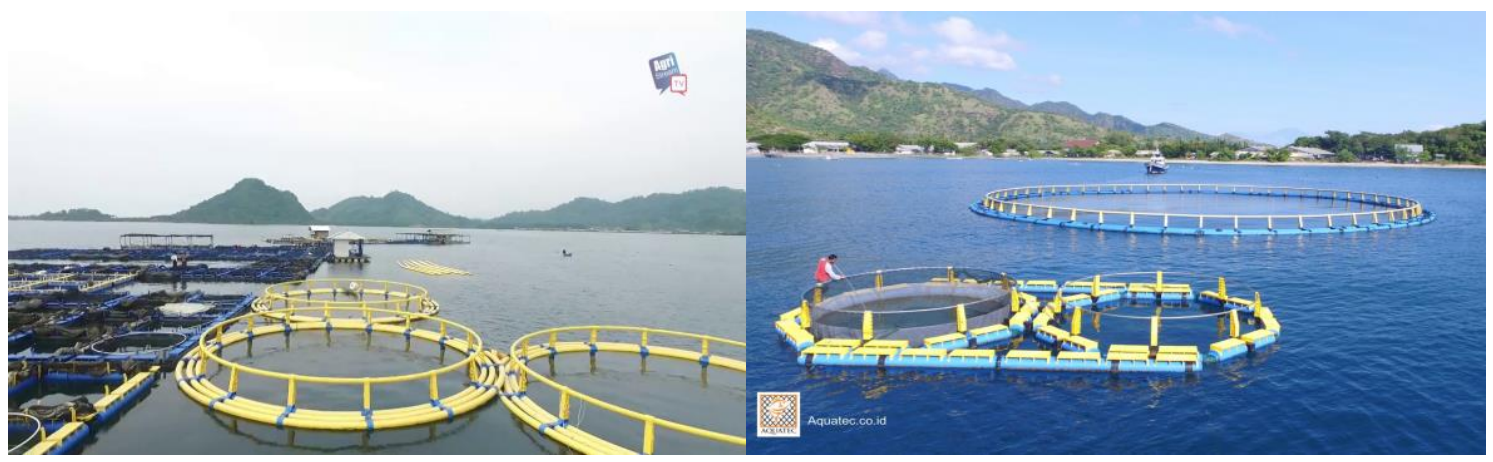

Gambar 1. Bentuk Keramba Jaring Apung Bulat

Sumber : https://aquatec.co.id/

Jenis ikan yang biasanya dibudidayakan dalam keramba ini seperti ikan nila, ikan mas, ikan lele, ikan bandeng, dan jenis lainnya. Budidaya ikan dengan keramba jaring apung merupakan salah satu cara budidaya pembesaran ikan yang efisien dan efektif digunakan masyarakat. 
Untuk bahan KJA jenis ini didesain kuat dan lentur sehingga mampu menghadapi ombak hingga ketinggian 2 hingga 3 meter. Alat apung dan komponen-komponen KJA biasanya terbuat dari bahan Prime Grade Polyethylene (PE) dengan anti-UV yang ramah lingkungan. Tidak menggunakan styrofoam atau bahan yang mencemari lingkungan, baik di dalam maupun di luar alat apung.

\section{Prinsip Arsitektur Ramah Lingkungan (Eco Friendly Architecture)}

Pada umumnya ada beberapa prinsip Eco Friendly Architecture seperti mengupayakan terpeliharanya SDA dan mengurangi dampak yang lebih parah dari pemanasan global melalui pemahaman perilaku alam. Mengelola tanah, air dan udara untuk menjamin kelestarian ekosistem melalui sikap ramah terhadap alam dengan pemikiran secara holistik dan kontekstual. Oleh karena itu untuk menghasilkan perancangan arsitektur ramah lingkungan yang ramah terhadap alam, dapat dilihat dari konsep perancangan. Pemikiran holistik yang sangat kompleks dan mencakup berbagai macam keilmuan sangat dibutuhkan pada perancangan arsitektur, bangunan berfungsi sebagai pelindung untuk manusia yang harus nyaman bagi penghuninya, efisien dan ramah dalam pemanfaatan sumber daya alam, terutama dalam penggunaan energi dan pembuangan limbah yang jelas. Pada pendekatan ekologi ada berbagai macam sudut pandang dan penekanan, namun semua mempunyai arah dan tujuan yang sama, yaitu prinsip konsep perancangan Eco Friendly.

Prinsip Arsitektur Ramah Lingkungan yaitu:

- Mengupayakan terpeliharanya SDA dan mengurangi dampak yang lebih parah dari pemanasan global melalui pemahaman perilaku alam.

- Mengelola tanah, air dan udara untuk menjamin kelestarian ekosistem melalui sikap ramah terhadap alam dengan pemikiran secara holistik dan kontekstual.

- Perancangan dilakukan secara teknis dan ilmiah untuk menciptakan kenyamanan bagi penghuni secara fisik, sosial dan ekonomi melalui sistem dalam bangunan.

- Penggunaan sistem pasif (alamiah) yang selaras dengan iklim setempat.

- Penggunaan material yang ekologis, setempat, sesuai iklim, menggunakan energi yang hemat mulai pengambilan dari alam sampai pada penggunaan pada bangunan dan kemungkinan daur ulang.

- Meminimalkan dampak negatif pada alam (limbah) dan meningkatkan penyerapan gas buang dengan menggunakan teknologi yang ramah.

- Menuju pada suatu perancangan bangunan yang berkelanjutan (sustainable).

Ada beberapa hal yang sangat dipertimbangkan dalam Arsitektur Ramah Lingkungan (Badan Pusat Statistik, 2014) antara lain:

- Mengurangi ketergantungan pada sistem pusat energi (listrik, air) dan limbah (air limbah, sampah) dan pemakai bangunan ikut dalam pemeliharaan bangunan.

- Memilih lokasi yang strategis. Hal ini dimaksudkan agar akses atau pencapaian bisa dilakukan dengan berjalan kaki atau bersepeda sehingga mampu mengurangi emisi atau gas buangan yang terlalu banyak dari kendaraan bermotor.

- Menghemat sumber daya alam yang tidak dapat diperbaharui dan efisiensi penggunaan energi dengan meminimalisasi penggunaan energi untuk AC, optimalisasi pada penggunaan sumber daya energi alternatif dan energi surya.

- Penyesuaian lingkungan alam setempat (memperhatikan orientasi terhadap matahari, angin, perubahan suhu serta penggunaan tumbuhan dan air sebagai pengatur iklim).

- Memelihara lingkungan (udara, tanah dan air) dan siklus peredaran alam. Contohnya dalam kegiatan penggunaan bahan bangunan harus memperhatikan rantai pembentuk bahannya (sebaiknya daur ulang). 


\section{METODE PENELITIAN}

Dalam melakukan tahap perancangan arsitektur ini maka diperlukan data-data yang mendukung, datanya dapat bersifat kualitatif dan juga data kuantitatif. Pendekatan studi yang digunakan dalam penelitian ini adalah pendekatan metode yang dilakukan adalah metoda deskriptif kualitatif dan kuantitatif, yang meliputi pengumpulan data dan teori mengenai Arsitektur Ramah Lingkungan, pembahasan teori - teori berdasarkan studi literatur / studi pustaka, perbandingan antara teori dengan konsep desain bangunan, pada fasilitas konservasi air dengan keramba jaring apung di Balige, Danau Toba.

\section{Metode Perancangan Arsitektur}

Sedangkan pendekatan desain yang digunakan adalah desain pragmatis yaitu penciptaan bentuk tiga dimensional atau proses desain secara pragmatis, mengacu pada proses coba-coba / mencoba-coba (trial and error), dengan memanfaatkan berbagai sumber daya (material) yang ada sedemikian rupa (Geoffrey Broadbent, 1978).

Tahapan-tahapannya :

a) Studi awal tentang alternatif bentuk tiga dimensional dari bangunan atau gedung yang dirancang yang dilakukan dengan cara membuat sketsa-sketsa bentuk awal bangunan,

b) Studi awal tentang alternatif bentuk tiga dimensional dengan cara membuat sketsa bentuk awal bangunan melalui sebuah program,

c) Studi awal alternatif dengan cara membuat model dan

d) Dalam tahapan pengembangan atau tahapan 'development design'.

\section{DISKUSI DAN HASIL}

Proyek Fasilitas konservasi air dengan keramba jaring apung ini berada di Danau Toba, Balige Provinsi Sumatera Utara. Tapak berada sekitar $3.6 \mathrm{~km}$ dari pusat kota kabupaten Toba dengan luas sebesar $\pm 40.000 \mathrm{~m}^{2}$ yang akan dibagi menjadi dua zona yaitu bangunan di darat dan konservasi KJA di air.

Menurut Badan Perencanaan Pembangunan Daerah menetapkan ketentuan Rencana Tata Bangun Kecamatan Balige yang termuat dalam Perda Kabupaten Toba no. 12 tahun 2017 (DATABASE PERATURAN, 2017) yaitu:

Koefisien Dasar Bangunan: 60\%

Koefisien Lantai Bangunan: maksimal 4

Garis Sempadan Bangunan: $5 \mathrm{~m}$

Koefisien daerah hijau: $5200 \mathrm{~m}^{2}$

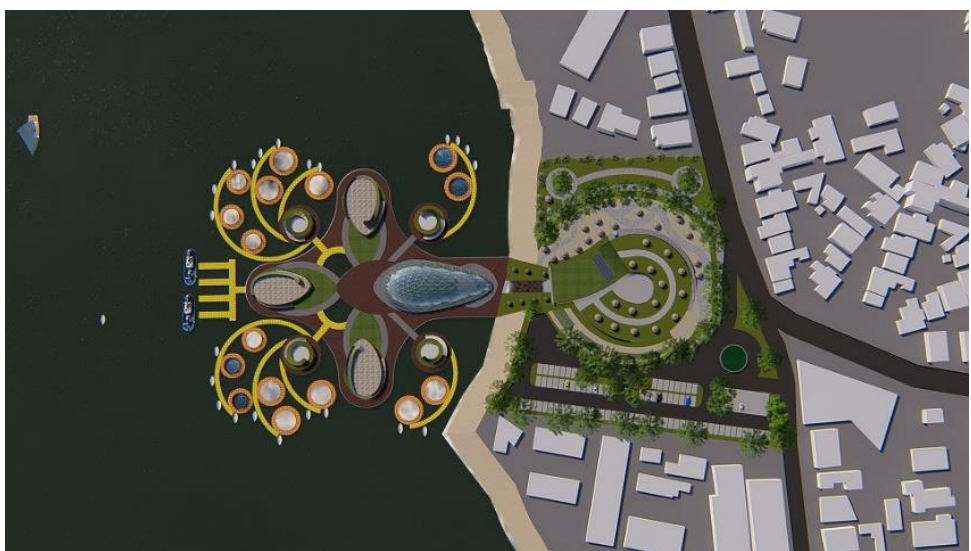

Gambar 3. Blok plan proyek konservasi air Sumber : Penulis 2021 


\section{Tapak dan Lingkungan}

Ekologi lahan dengan tujuan untuk menghidupkan kembali hubungan antara geologi (tanah), air dan habitat yang ada di lingkungan tersebut. Bangunan proyek konservasi air berorientasi ke arah Danau Toba yang menyebabkan pengembangan landscape pada bagian ini sangat penting dalam meningkatkan hubungan antara bangunan konservasi air dengan lingkungan disekitar danau. Hasilnya sebagian besar penembangan lahan sebagai ruang terbuka hijau. Penerapannya :

* Menjaga keanekaragaman hayati dengan penanaman beberapa tanaman pada sekitar bangunan dan green roof sehingga serangga dan burung dapat berkembang biak dan hidup di proyek ini.

* Tersedianya kolam biologi penelitian sebagai tempat pengolahan air danau dan limbah pakan ikan hasil budidaya keramba jaring apung

* Penanaman beberapa vegetasi seperti berbagai jenis macam pepohonan, bunga dalam menggambarkan lingkungan alami untuk berbagai serangga, burung-burung, dan hewan lainnya.

* Pengembangan ruang luar seperti ruang pasif sebagai ruang-ruang yang dibentuk bukan difungsikan sebagai tempat manusia melakukan kegiatan utama tetapi mengintegrasikan objek bangunan dengan aspek alam dan kultur sosial yang berada di sekitar kawasan untuk menciptakan elemen ruang yang harmoni. Ruang luar ini berbentuk seperti taman pasif, area hijau terbuka untuk penyerapan air hujan.

Tabel 1. Kriteria kesesuaian tapak perancangan dengan lingkungan sekitarnya

\begin{tabular}{lll}
\hline \multicolumn{1}{c}{ Faktor } & \multicolumn{1}{c}{ Alasan } & \multicolumn{1}{c}{$\begin{array}{c}\text { Kesesuaian } \\
\text { Kriteria Tapak }\end{array}$} \\
\hline Gangguan alam & $\begin{array}{l}\text { Dapat merusak konstruksi keramba sehingga memperpendek } \\
\text { umur rakit }\end{array}$ & Sesuai \\
\hline $\begin{array}{l}\text { Adanya } \\
\text { pencemaran danau }\end{array}$ & $\begin{array}{l}\text { Adanya makhluk hidup, zat, energi atau komponen lain } \\
\text { kedalam lingkungan danau oleh kegiatan manusia sehingga } \\
\text { kualitasnya turun }\end{array}$ & Sesuai \\
\hline Keterkaitan dengan \\
$\begin{array}{l}\text { pengguna sarana } \\
\text { danau lain }\end{array}$ & $\begin{array}{l}\text { Daerah yang merupakan tempat lalu lintas kapal harus } \\
\text { dihindari untuk lokasi budidaya kerapu, adanya kapal tanker } \\
\text { minyak yang berlabuh harus dijauhi karena kapal tersebut } \\
\text { biasanya membuang minyak ke dalam perairan }\end{array}$ & \\
& & \\
& & \\
& $\begin{array}{l}\text { Memperhatikan lokasi yang dekat dengan jalan besar, pasar, } \\
\text { pelelangan ikan, dan pemasok sarana sangat memberi } \\
\text { kemudahan dalam operasional, adanya sumber listrik, } \\
\text { telepon dan sarana penghubung lainnya }\end{array}$ & Sesuai \\
& $\begin{array}{l}\text { Tersedianya jalan darat yang mengakses ke lokasi budidaya } \\
\text { akan memudahkan transportasi benih dan hasil panen }\end{array}$ & Sesuai \\
&
\end{tabular}

Sumber : Penulis 2021

Proses perancangan dimulai dengan pembentukan gubahan massa melalui metode pragmatis. Pengelompokan berdasarkan ini perhitungan kebutuhan ruang dan peletakan fungsi ruang. Metode Desain Pragmatis adalah penciptaan bentuk tiga dimensional atau proses desain secara pragmatis, mengacu pada proses coba-coba / mencoba-coba (trial and error), dengan memanfaatkan berbagai sumber daya (material) yang ada sedemikian rupa. 

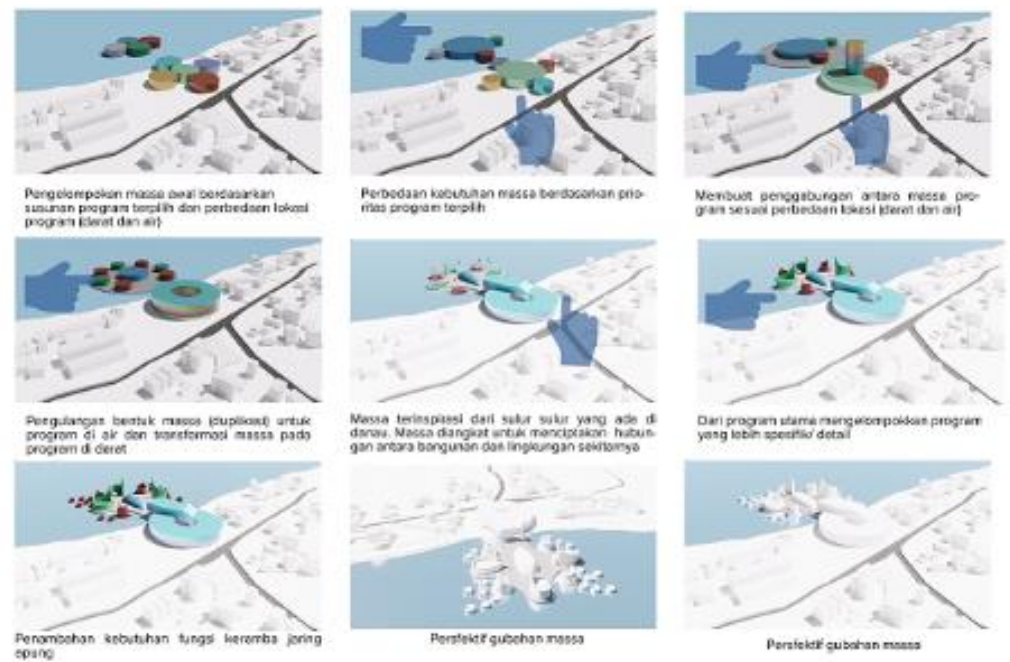

Gambar 4. Proses pembentukan massa

Sumber : Penulis 2021

\section{Efisiensi Air}

Pada proyek konservasi air ini menyediakan tempat bagi makhluk hidup yang semula ada disana dengan konsep baru serta menggabungkan kegiatan edukasi dan konsep wisata dekat dengan alam sekitarnya. Selain itu efisiensi dalam menampung air hujan dengan penggunaan green roof pada bangunan dapat memperbaiki kualitas air dan untuk membantu penggunaan air seperti menyiram tanaman di dalm proyek konservasi air ini. Caranya dengan mengalirkan air hujan ke area berumput yang telah memiliki penyaring alami dalam mengurangi partikel padat dan dialirkan sesuai kebutuhan masing masing tanaman. Penerapannya.

- Merancang konsep Green Roof yaitu menanami sebagian besar atap dengan tumbuhan yang berfungsi sebagai media penyerapan air hujan. Air hasil resapan lalu diolah dan digunakan kembali untuk menyiram tanaman dan membantu keperluan penyiram toilet.

- Sebagai sarana pendidikan umum mengenai konservasi air, upaya pelestarian dan pengelolaan air kepada masyarakat juga pengelola bangunan.

- Menanami vegetasi alami untuk menghemat energi dan air, sekaligus tanaman bermanfaat sebagai buffer dan penghalang yang mampu menyerap debu.

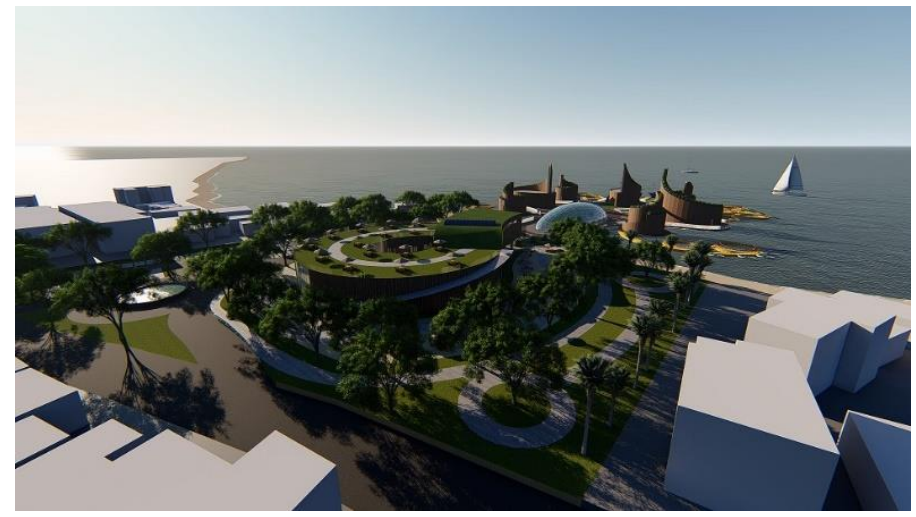

Gambar 5. Penerapan atap green roof pada bangunan

Sumber : Penulis 2021

\section{Energi}

Desain dinding bangunan yang menggunakan material kayu sebagai penyerap dan meminimalkan panas sinar matahari serta menjaga kelembaban suhu dalam ruangan agar tetap nyaman tanpa menggunakan AC. Penggunaan vegetasi di atap bangunan juga menciptakan bagian bayang yang meningkatkan isolasi panas sinar matahari ke dalam bangunan. 
Desain dinding kaca meningkatkan efisiensi pencahayaan alami yang dapat mengurangi penggunaan listrik. Ada beberapa sensor aktif yang secara otomatis mematikan pencahayaan buatan/lampu jika ruangan kosong karena sensor akan menilai pencahayaan cukup atau tidak. Untuk keperluan bangunan, penggunaan energinya dapat dikurangi yaitu menggunakan rancangan solar panel yang dapat menghasilkan energi listrik. Penerapan sistem solar panel berdasarkan konsep bangunan yang ada pada fasilitas konservasi dapat memberikan dampak positif yaitu dapat mengoptimalkan penggunaan energi listrik serta mengefisiensi, mengurangi penggunaan energi listrik.

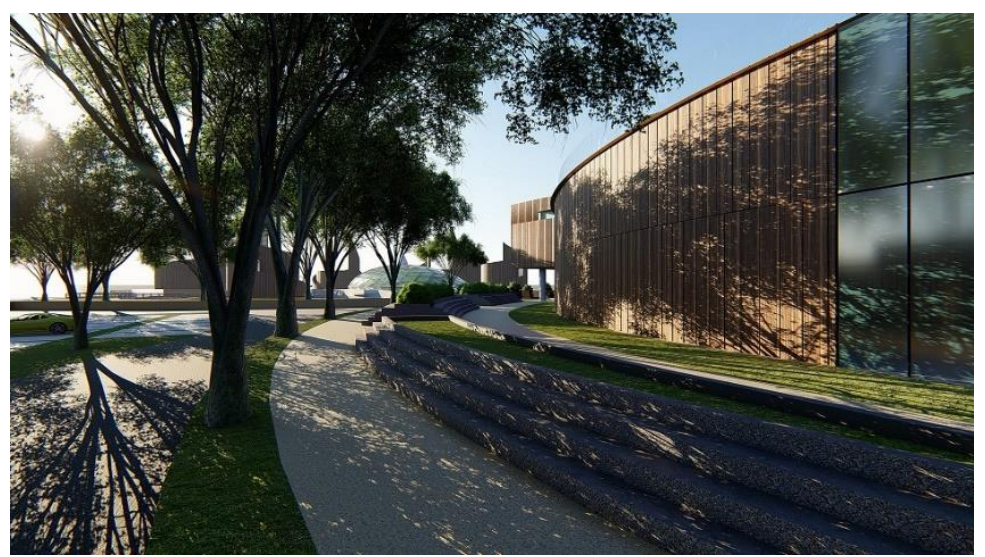

Gambar 6. Penerapan dinding kaca dan kayu pada bangunan Sumber : Penulis 2021

Penerapannya:

- Jendela kaca besar yang menghadap ke arah selatan digunakan untuk memaksimalkan pencahayaan

- Untuk menstabilkan temperatur ruangan (hemat listrik), digunakan kipas angin. Sedangkan untuk mengontrol pencahayaan, akan digunakan sensor sehingga lampu hanya akan menyala jika dibutuhkan.

- Dinding kayu dapat menghemat energi karena bangunan dapat terjaga dari banyaknya panas dan cahaya dari matahari langsung.

- Untuk memenuhi kebutuhan bangunan, digunakan solar panel yang terbuat dari semikonduktor dan diletakkan pada atap bangunan untuk menghasilkan listrik.

- Agar bangunan terlindungi dari sinar matahari langsung maka digunakan Green Roof pada atap. Green Roof ini berfungsi untuk mengisolasi bangunan dari suhu dingin di malam hari dan suhu panas di siang hari. Dengan demikian maka kebutuhan energi dapat dikurangi.

- Selain itu berbagai terobosan baru dalam dunia perikanan juga memperkenalkan pengelolaan limbah keramba jaring apung dengan akuaponik yaitu penggabungan antara sistem budidaya akuakultur (budidaya ikan) dengan hidroponik (budidaya tanaman/sayuran tanpa media tanah). Sistem ini mengadopsi sistem ekologi pada lingkungan alamiah, dimana terdapat hubungan simbiosis mutualisme antara ikan dan tanaman. 


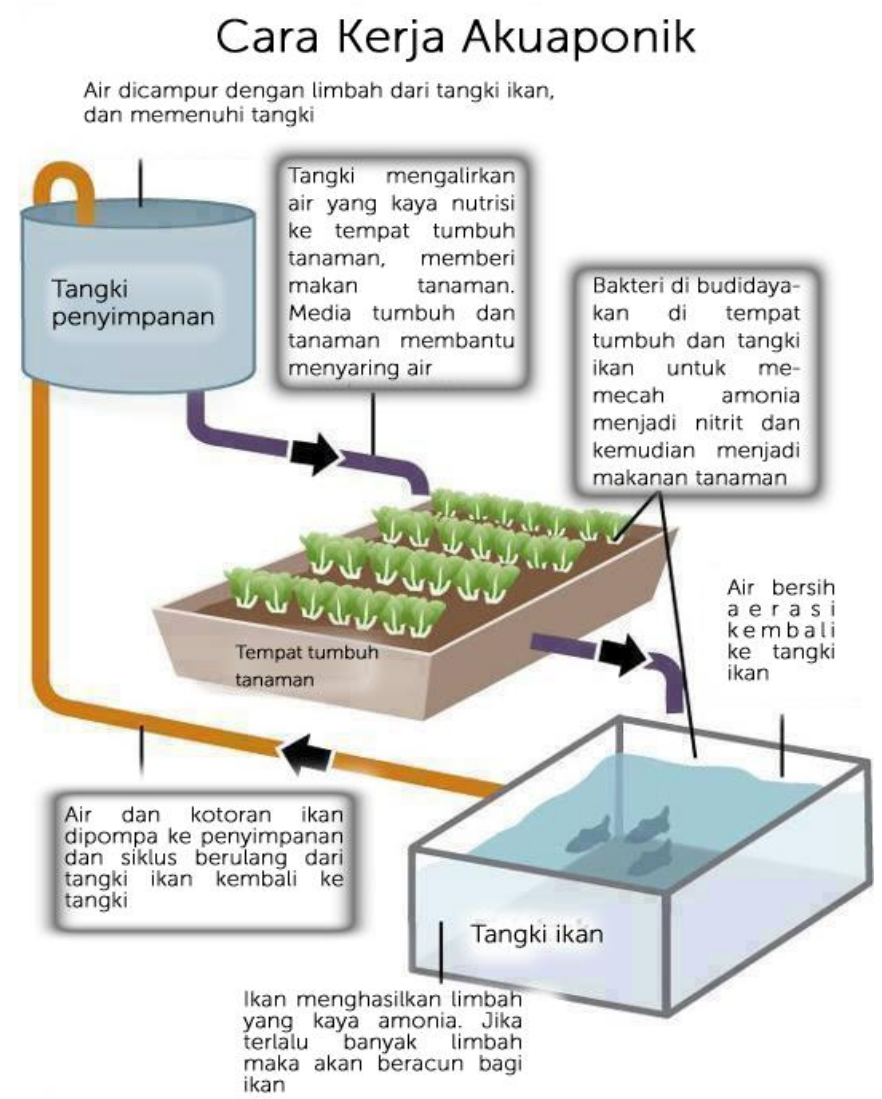

Gambar 7. Cara Kerja Akuaponik

Sumber : Penulis 2021

\section{Material Bangunan}

Proyek ini menerapkan prinsip daur ulang dengan mempertimbangkan penggunaan kembali elemen bangunan. Pada eksterior menggunakan material kayu. Untuk jalan dan dinding luar dapat digunakan batu-batuan. Material yang mempunyai tingkat emisi kimia yang rendah dan dapat diperbaharui digunakan untuk dinding dalam bangunan.

Penerapannya:

- 11 \% dari keseluruhan material bangunan terbuat dari material yang didaur ulang. Menggunakan material daur ulang, seperti batu-batu yang berasal dari lingkungan sekitar atau dapat disebut batu daur ulang. Batu-batu tersebut digunakan untuk dinding dan tangga. Ada juga balok baja dan tulangan pada beton yang terbuat dari logam daur ulang.

- Penggunaan material sumber daya alam yang cepat berproduksi kembali seperti bambu. Bambu seperti ada pada pintu untuk ruang dalam yang terbuat dari bambu.

- Perletakan material sesuai daya tahannya. Contoh kayu yang mempunyai daya tahan kuat, anti lapuk dan busuk sehingga cocok digunakan pada dinding ruang luar.

\section{Material struktur apung}

Penerapannya :

- Pemakaian material struktur apung $b$-foam dengan teknologi EPS :

- Bahan Bangunan Ramah Lingkungan Expanded Polystyrene System (EPS), adalah produk yang ramah lingkungan

- Safe : tidak melepaskan zat-zat beracun dan berbahaya serta benar-benar tanpa efek samping. Tanpa bahan chlorofluorocarbons (CFC) atau hydrochlorocarbons (HCFC). Karena tidak mengandung bahan organik, menghambat pertumbuhan mikroorganisme dan jamur. Tidak mengalami kerusakan permanen jika terkena uap atau kelembaban. 
- Recyclable: tidak ada bahan limbah yang dihasilkan selama produksi dan proses produksi untuk MPANEL yang bertujuan untuk mengoptimalkan dan meminimalisir limbah. Setiap sisa EPS sisa daur ulang secara langsung di Pabrik Produksi.

- Non-Toxic: Tidak menciptakan efek alergi yang merusak kesehatan untuk mereka yang memproduksi atau mengerjakannya.

- Self-Extinguishing: EPS yang digunakan sebagai bahan MPANEL dapat meredam kebakaran, material tidak menghasilkan api, juga tidak merambatkan kebakaran.

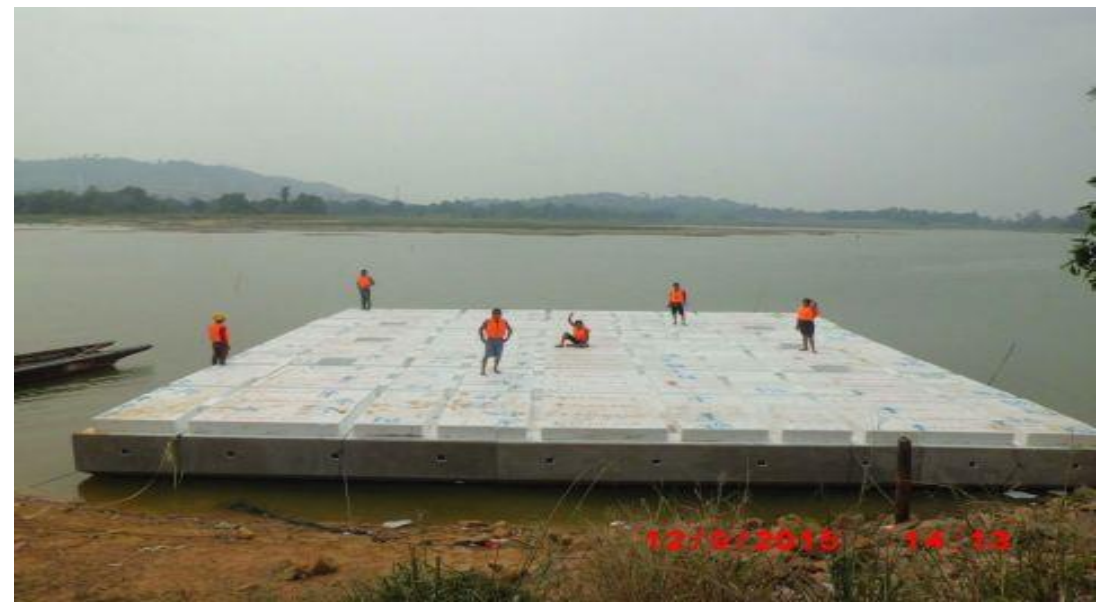

Gambar 8. Struktur apung b-foam Sumber : Penulis 2021

\section{Kualitas Pencahayaan dan Penghawaan dalam Ruang}

Selain pencahayaan alami dan buatan pada bangunan, penggunaan lampu pijar rendah dapat digunakan jika diperlukan. Terdapat juga sensor yang dipasang pada setiap ruang untuk mematikan lampu ketika tidak ada pemakai ruangan dan akan menyala jika pencahayaan alami dirasa kurang mencukupi. Penggunaan AC dapat dikurangi dengan jendela yang dapat dibuka dapat mengurangi penggunaan AC. Penerapannya:

- Menggunakan jendela yang besar agar penglihatan ke area sekitar terasa nyaman dan juga memaksimalkan pencahayaan alami dengan membuat langit-langit yang tinggi pada bangunan. Pada selatan bangunan, cahaya dan panas yang berlebihan diatasi dengan dinding kaca. Cat putih juga digunakan agar dapat memantulkan cahaya.

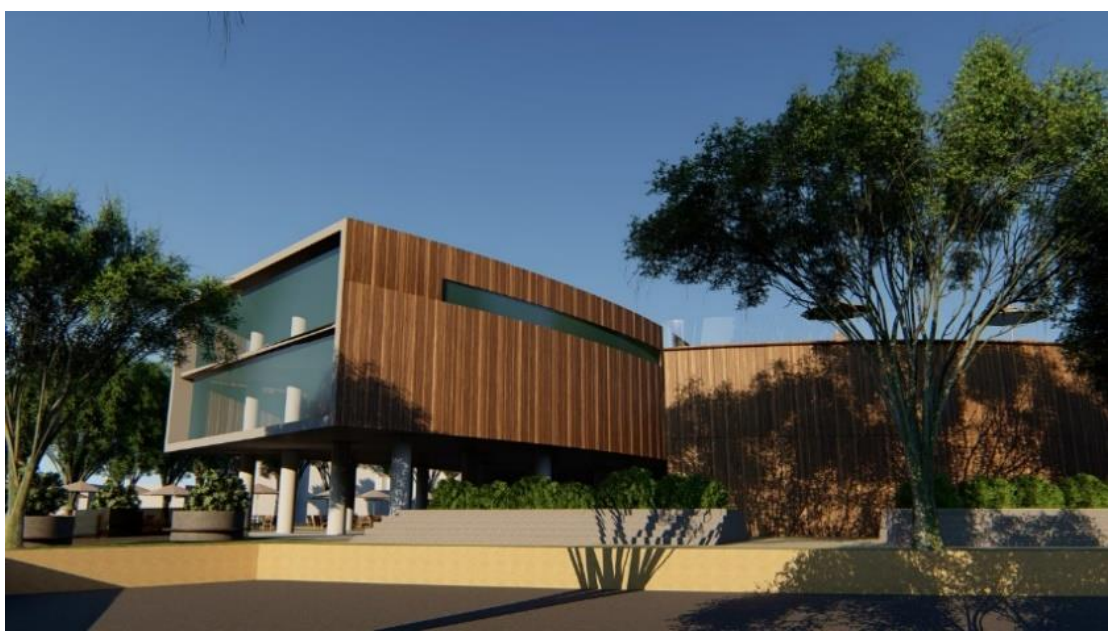

Gambar 9. Penerapan pencahayaan dan penghawaan dalam ruang Sumber : Penulis 2021 


\section{KESIMPULAN DAN SARAN}

\section{Kesimpulan}

Konsep berkelanjutan pada proyek ini terlihat dari pengaplikasian penggunaan material keramba jaring apung, struktur apungnya dan pengolahan limbah kja melalui sistem akuaponik. Dan melalui desain bangunan yang hemat energi, yaitu sistem bangunan yang didesain agar mengurangi pemakaian listrik seperti penggunaan solar panel pada bangunan, untuk pencahayaan dan tata udara. Terlihat dari orientasi bangunan diletakkan antara lintasan matahari dan angin, letak gedung tegak lurus terhadap arah angin, menghadirkan pohon peneduh di halaman yang dapat menurunkan suhu, memakai material alami yang lebih banyak menyerap panas, seperti penggunaan kayu, green roof untuk mengurangi panas yang masuk pada bangunan sekaligus penyuplai oksigen, memperbanyak penanaman tumbuhan hijau serta pengolahan air pada bangunan "Fasilitas konservasi air dengan keramba jaring apung di Balige, Danau Toba" dalam mendukung perbaikan lingkungan agar lebih baik, menjaga dan memelihara bumi ke depannya.

\section{Saran}

Dalam merancang suatu bangunan, sebaiknya memperhatikan hubungan dengan lingkungan sekitarnya. Kehadiran bangunan harus memberikan dampak baik/positif bagi masyarakat, lingkungan sekitarnya dan masa depan bumi ini.

\section{Referensi}

Aquatec International (2017), Sarana kelautan, perikanan, dan parawisata karya anak bangsa, diakses pada 25 Juni 2021, <https://aquatec.co.id/produk-kami/.

Berge, B. (2009). The Ecology of Building Materials (second edition), London: Architectural Press.

Frick, H. dan Suskiyatno, FX. B. (2007). Dasar-dasar Arsitektur Ekologis. Yogyakarta: Kanisius \& Bandung: ITB.

Hartami, P. (2008) Analisis Wilayah Perairan Teluk Pelabuhan Ratu Untuk Kawasan Budidaya Perikanan Sistem Keramba Jaring Apung. Institut Pertanian Bogor (IPB).

Kadir, A. (2010). Metode Penelitian. Pustaka Pelajar

Menteri Kelautan dan Perikanan. 2012. Kepelabuhan Perikanan. Jakarta : Menteri Kelautan dan Perikanan.

Putra, B. E. (2020), B-foam Floating Structures, diakses pada 25 Juni 2021, <http://www.bfoam.com/floating/.

Satwikasari, F,. L. H. (2018). Enchancing Thermal Environtmen Quality With Voids and As a Passive Design Strategy Towards Sustainable and Healty Living. Purwarupa.

Siagian, Indira Shita. (2005). Bahan Bangunan yang Ramah Lingkungan (Salah Satu Aspek Penting Dalam Konsep Sustainable Development). Universitas Sumatera Utara.

Sutopo, A., Fitriana, D., dan Rahmi, A. (2014). Indicator for Sustainable Development Goals. New York: SDSN. 